\title{
特別寄稿
}

\section{「選奖受賞者からのメッセージ」 を始めるにあたって}

7月号の本誌でご紹介し A

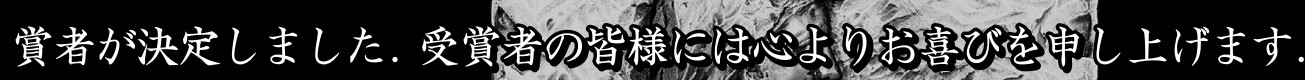

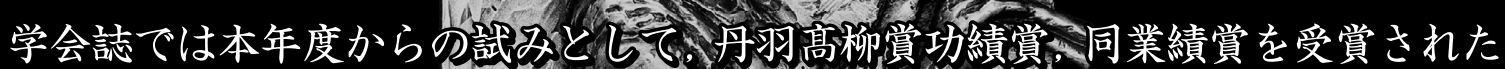

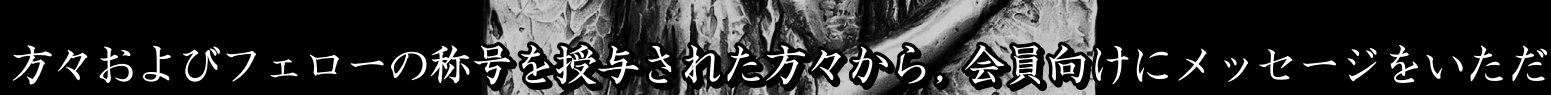

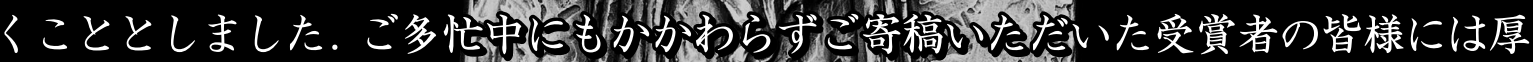

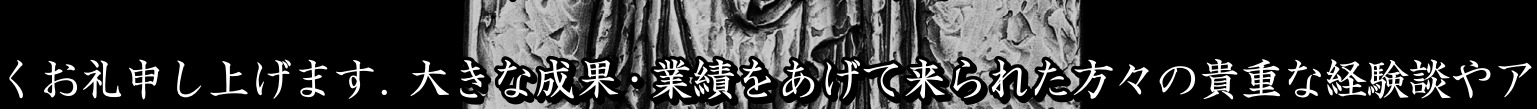

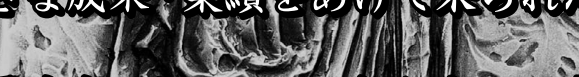

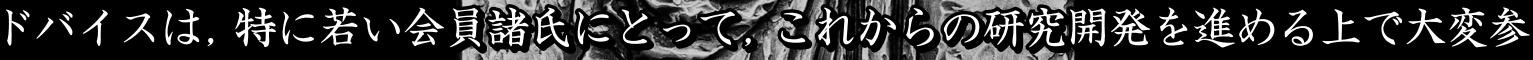

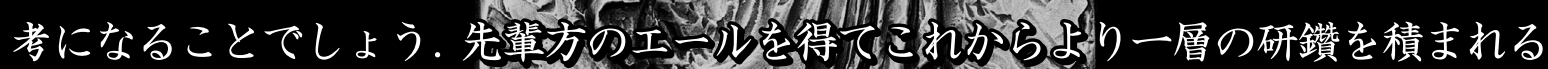
ことを期待いたします。

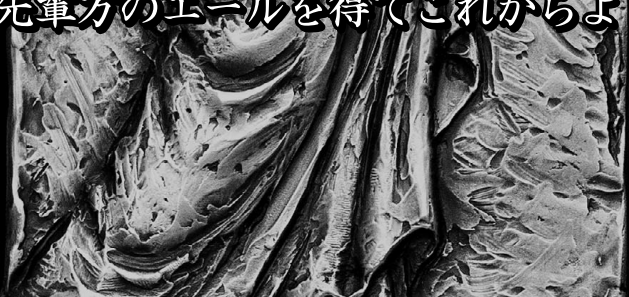

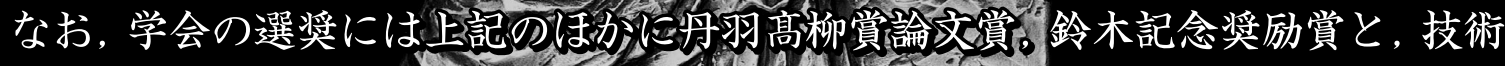

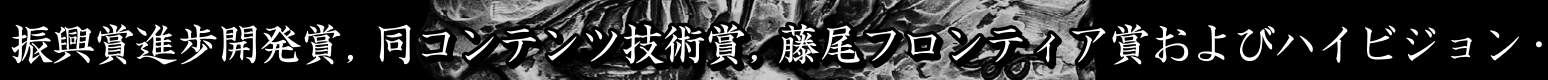

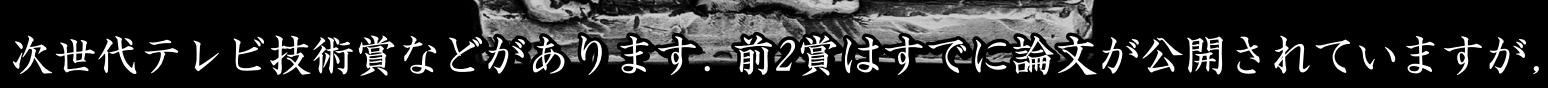
後の4賞についてもオンラインジャーナル12月号に招待論文として詳細な情報をい ただくこととなっています。こちらも是非ご覧いただきますようご案内いたします。 


\section{エレクトロニクスに産業の未来を期して}

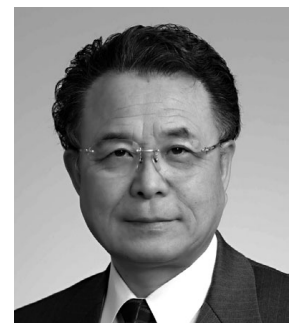

2012年度丹羽高柳賞功績賞受賞

内田 龍 男

国立高等専門学校機構 理事/国立仙台高等専門学校 校長

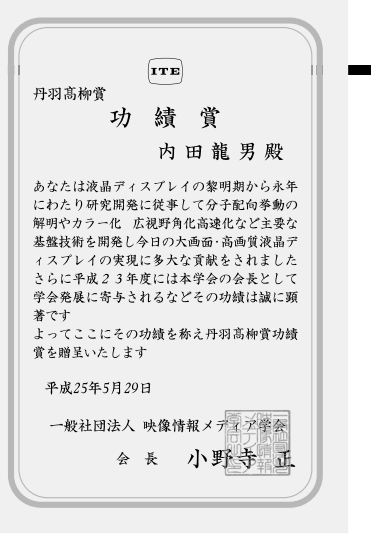

日本の基幹産業となっていた繊維産業, 造船を中心とした重工業, 化学産業, 鉄鋼産業などがいずれも相次いで構造 不況に見舞われて厳しい時代を迎えた歴史があります。そして現在，それがエレクトロニクス産業に及んでいます．特 に一世を風びした家電産業に厳しい風が吹いています。

しかし，上述の繊維や化学産業は高機能フィルムや炭素繊維などの高性能・高機能素材，医薬，医療関係の高付加価 值材料などの分野で復活を果たしています。また，重工業は，鉄道，建設機器，航空機，あるいは電力などのインフラ 産業で元気を取り戻しています，さらに，鉄鋼産業は，自動車用などの高機能鋼材などで世界を席巻しています，この ようにかっての基幹産業の主立った企業が復活していますが，大きな変革や淘汰があったことも確かです。復活した企 業に共通して言えるのは，それまで培ってきた基盤技術を基にして新たな素材や用途を開拓し，技術を磨き上げ，時代 が求める分野に適合させているところです. また, 総じて, 会社全体が前向きで, 新しい技術に強い関心を示し, 常に 次の時代を読もうとしている姿勢に溢れているように感じられます.

エレクトロニクス産業にとっても，来るべきものが来たということかと思います．しかし，これまで培ってきた技術 と人材を必要としている未来は限りなく広いと思われます。志ある企業や社員にとって，今こそチャンスです．エレク トロニクスの新たな挑戦と発展を願ってやみません.

\section{固体撮像素子はこれからも面白い!}

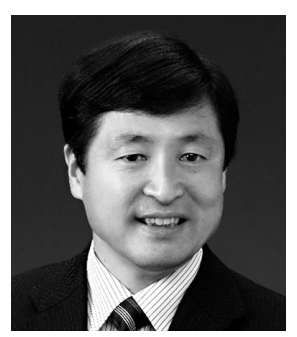

2012 年度丹羽高柳賞功績賞受賞 寺西信一

兵庫県立大学 高度産業科学技術研究所 特任教授

静岡大学 電子工学研究所 特任教授

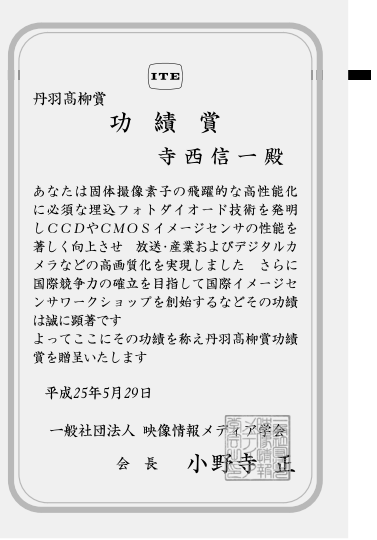

固体撮像素子は 2011 年に 21 億個も生産され, 携帯電話カメラ, PC・タブレット, デジカメ, 監視, 車載, ロボッ ト・FA，医療など社会のあらゆるところで使用され，産業・文化に大きく貢献しています．固体撮像素子の開発は 1960 年代後半にスタートしましたので，50数年でここまで成長したことになります．実用化前夜から今日まで固体撮像 素子の開発に携わることができ，その上，立派な賞をいただけたことは僥倖と存じます．いろいろな方々の知恵を集め， 技術開発が行われてきました，社内では，優れた先輩や仲間に恵まれ，すばらしいチームプレーができましたし，社外 の方々からは特に当学会研究会後の懇親会などでお教えをいただきましたことは感謝に堪えません. ビジネス的には大 輪の花となりました固体撮像素子ですが，技術的にはよちよち歩きの状態で，これから大きな技術革新がなされ，その 技術革新が新しい需要, 市場をもたらすと思っております.いろいろな分野でその分野に適した使いやすい固体撮像素 子を求めておられます，私は還暦を迎えたのを機会に，まだまだ一技術者として，生涯一技術者として，固体撮像素子 の開発に従事していくという決意を新たにしました。これからも多くの方々と協力して, 直球, 変化球の固体撮像素子 を楽しみながら開発していきますので，今後もよろしくお願いします. 


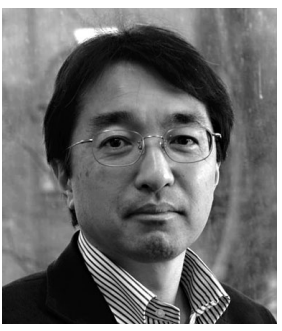

\section{2年度丹羽高柳賞業績賞受賞} 相 澤 清 晴

東京大学 大学院情報理工学系研究科 電子情報学専攻 教授

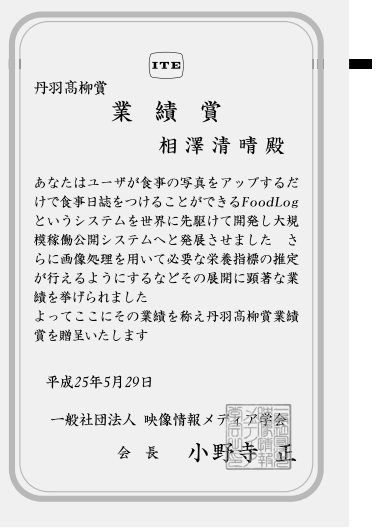

1990年代終わりごろから行ってきたライフログの研究ですが, 食事ログという焦点を持つことで, 逆に, 研究には広 がりが出ました，それを認めていただけたことを，大変有難く思っています．もともと私が研究をスタートした時は, 画像符号化・圧縮が研究テーマでした，その後，打拈よそ10年強抒きくらいに，研究の中心テーマに，変遷がありまし た。センシングのハードに関わるようなことまで取組んでいた時もあります．研究の内容は，人さまざまです．自分と しては, 課題や目標の設定そのものが, 新しいこと，ユニークであることを一番大事に思っています，まだだれも試み たことのない課題だと思えることが大きな原動力になってきました．また，研究の進め方も人さまざまです．自分自身 をみると，ある課題や目標へ取組んでも，そこにずっととどまるより，新たな展開を絶えず模索してきたように思いま す。な拀，食事ログに関して言えば，最初は単に記録をとるだけでしたが，内容に関する処理やシステム，社会的な実 装と幅が広がり, スタートアップの会社までできて, 健康・医療関連の分野との接点も増え, 課題そのものが単なる情 報処理の課題から大きく変化しているのを感じています。どこまで続けられるかは未知数ですが，まだまだ，やること がありそうです。

\section{若し会員の方々へ}

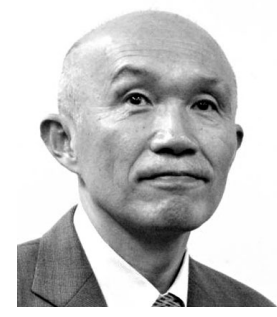

2012年度丹羽高柳賞業績賞受賞 江上典 文

近畿大学 産業理工学部電気通信工学科 教授

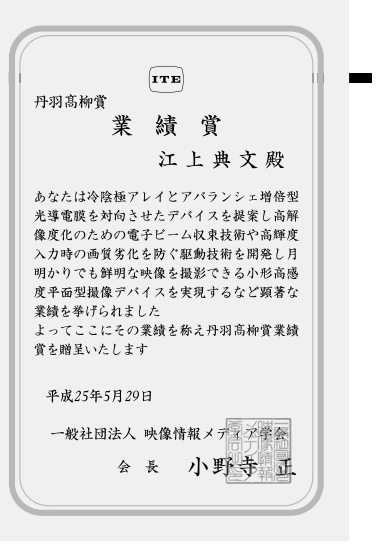

人間，歳をとると，よく「近頃の若い者は--」という言葉を口にします．ご多分に漏れず，私もその一人です．この言 葉は年配者の愚痴のようにも聞こえますが，一方で，若い方々に対して「もっと，やれるはず」，「がんばってください」 というエールでもあります.

ご存知のように, 映像分野や情報分野の進歩は日進月歩で, 世界中でし烈な競争が繰り広げられています。この競争 を勝ち抜くには大胆な提案とスピード感を持った実行力とが必要です。また, 私が携わってきたイメージセンサの分野 ではセンサの性能がそろそろ物理限界に達しつつあります。これを打破して次世代のセンサを開発するには, 従来の延 長線上にはない新たな発想が不可欠です。

大胆な提案や独創的な発想は若ければできるというものではありませんが, やはり若さはこれらを可能とする強力な 武器だと思います. 未来の担い手である若い方々には, 現在携わっていることを一歩一歩, 着実に進め, 確固たる実績 を積み重䄈るともに，「時代を見通す目」と「考元抜いた末の直観を信じる勇気」とを養い，ここぞというタイミング を見計らって大胆かつ独創的なことにぜひ挑戦していただきたいと切に願っています.

これからも「近頃の若い者は---」と言いつつ, エールを送り続けたいと思います. 


\section{映像情報メディアは常に進化する}

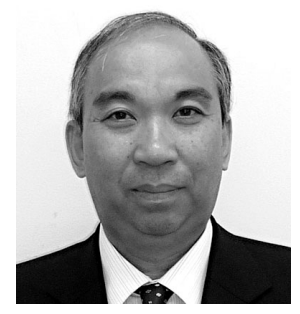

2013年フェロー称号授与者

栗 田 泰 市 郎

NHK 放送技術研究所 新機能デバイス研究部 研究主幹

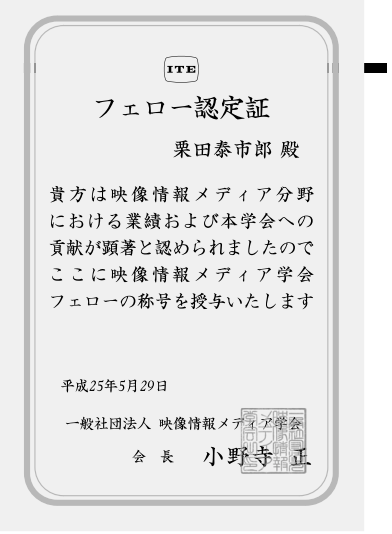

この度, 映像情報メデイア学会から名誉あるフェローの称号を授与していただきました．誠に光栄に存じます．長年 映像情報メディアに関わってきた一員として，大変に嬉しく感じております。これも，今までご指導ご鞭撻いただいた 諸先輩方，一緒に仕事をさせていただいた方々の扔かげによるものと媣く感謝しております.

映像情報メディアの分野では今，8K超高精細映像によるスーパーハイビジョン放送実現への期待が高まっています. スーパーハイビジョンの素晴らしさは疑う余地がありません. しかし, 好運にもハイビジョンとスーパーハイビジョン の 2 大映像メディアの両方を経験できた人間の一人として感じることは, スーパーハイビジョン放送の開始も, 映像情 報メディアの進化に打いては一つの通過点であろうということです。もちろん，放送開始のための課題やそれらを克服 する作業の困難さは今後も大変なことでしょう。しかし，映像情報メディアはその後も進化し続けるでしょう，ハイビ ジョンの後にスーパーハイビジョンが生まれたように.

その新たな進化を生み出すのは, 本学会の会員, 特に若い会員の方々であろうと信じています. 若い会員の方々には, 斬新な視点と大きな時間軸を持って, 新たなアィデアを創出してほしいと思います. それらにより, 夢のような, ある いは夢を超える，素晴らしい映像情報メディアやそのディスプレイが生みだされていくことを大きく期待しています.

\section{今，何を開発するか？}

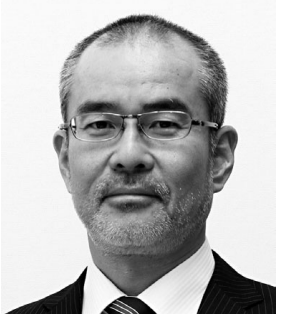

2013年フェロー称号授与者 杉 浦 博 明

三菱電機株式会社 デザイン研究所 所長

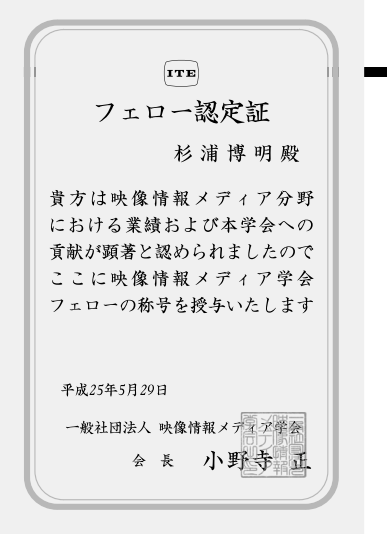

このたび，関係各位のご支援のおかげでフェロー会員に認定していただきました。私は，1982年に三菱電機に入社し ましたが, 最初に加入した学会が当時のテレビジョン学会 (現映像情報メディア学会) です。 入社した当時は, 固体撮像 素子を使ったビデオカメラの開発を担当していました，その後，プロジェクタやPCモニタなどのディスプレイの開発 も担当するようになり, 複数デバイス間の色合わせという課題に直面しました. 当時, カラーマネジメントという言葉 もない時代に, 将来, 映像・画像機器に扔いて色を合わせるとか正しい色あるいは好ましい色を再現する技術が重要に なると感じ，その技術に関する開発に着手しました。技術開発と並行して，カラーマネジメント技術拉よび各種映像・ 画像機器の色彩特性測定方法に関する国際標準化を, 国際電気標準会議 (IEC)において推進しました. 関連する知的財 産権も数多く獲得するとともに，論文・学会発表など学術的な成果も充分あげることができました.

重要なことは, 色について他の研究者が課題としてとらえていない時代に, 他に先んじてその技術を研究開発したこ とが多くの成果に結びついたということです.

若い会員の皆様に申し上げたいことは, 皆様の周りにも他の研究者がまだ気が付いていない課題が何かあるはずです. それを見つけて大きな成果に結び付けていただければと思います. 大事なことは「今，何を開発するか？」ということです. 


\section{あきらめないで}

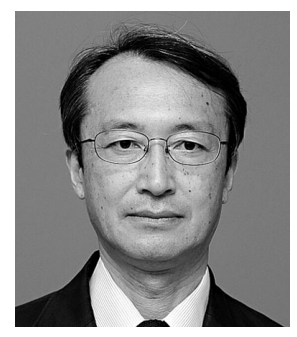

2013年フェロー称号授与者

山 崎順 —

一般財団法人NHKエンジニアリングシステム システム技術部長

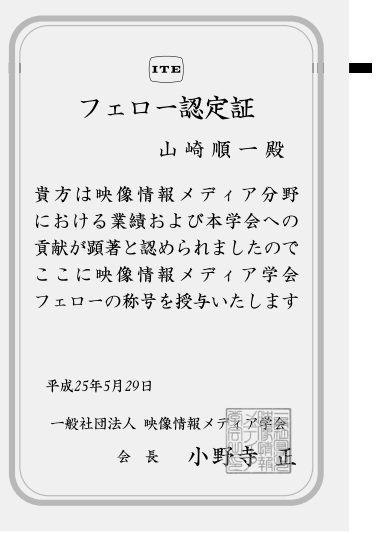

この度は, フェローの称号を戴き，ありがとうございました。

「ハイビジョン超高感度カメラの開発・実用化と宇宙分野への応用に関する貢献」という推奨理由をいただきました. 振り返れば， 30 余年，ハイビジョン用撮像管の電子銃の研究からスタートし，人間の眼の感度を越える超高感度カメラ, スポーツなどの速い動きを滑らかに映す高速度カメラ，紫外線に感度を持っている昆虫が見た世界を描く不可視光力 ラー化カメラなどを開発しました。また，「すばる望遠鏡」や「しし座流星群」「「スペースシャトル」，「国際宇宙ステー ション」など, 宇宙番組を支える各種カメラを開発. そして月探查衛星「かぐや」に 7 年の歳月をかけ苦労の末に搭載でき たカメラが「月の地平線から昇る地球の出」を撮影しました（当会の動画コンテンッ一覧ページ (http://www.ite.or.jp/data/c/?p=douga) を参照)。最近では, 宇宙から見た夜の地球や, 深海ダイオウイカを撮影したカ メラの開発を手掛けました，実用化が難しいと言われていた技術や，途中で継続があやしくなり挫折しかけた開発もあ ります。でも，もしこのカメラが実現したら今まで見たことのない世界が描け，人々に感銘を与えることができるだろ うという信念あるいは夢を心に秘めて，あきらめずに続けたことが完成に結びつきました。

是非若い人たちも, 自己の目標に向けた取組みを最後まで継続してください.

\section{研 究 生 活}

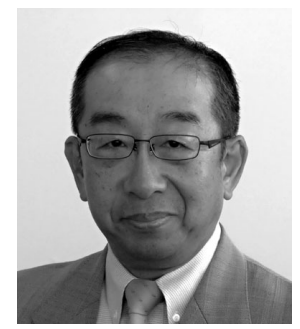

2013年フェロー称号授与者 和田正裕

株式会社 KDDIテクノロジー 特別顧問

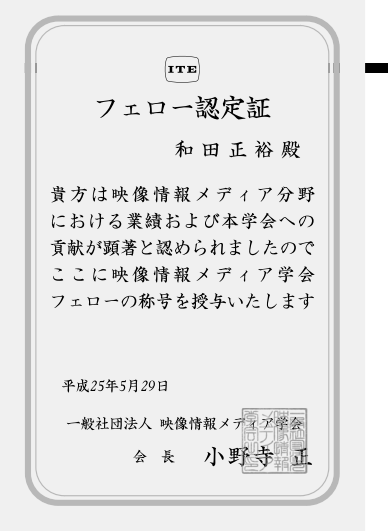

昔々，研究所に配属されたころ，厳しい上司から研究生活を快適に過ごすコツを伝授された。 曰く，ネタのあるなし に関係なく年次大会には必ず投稿せよ，成果が出たら論文を書くのではなく論文を書くと決めて成果を出せ，2年に 1 件はフルペーパを書け．当時は随分と無体なことを言うと思ったが，気が付けば部下に同じことを言っている。当然， 年次大会の前は苦痛だったが，無理やりネ夕を捻くりだしてみると，案外良いアイデアだったりした。また発表前に行 う Q\&Aの準備は研究を深化させる良い方法であったし, 発表当日は刺激的な質問を頂くこともできた。 なにより度胸 がついたし，顔も覚えてもらえた。一方，論文を書くとそれまでのさまざまな研究成果が結びつくとともに，研究の抜 けや漏れに気づくことができた。ささらに首尾よく採録された時の達成感は，日頃の憂さを晴らす何よりの薬だった．私 のような急け者が長く研究生活を続けることができたのは，このアドバイスのおかげだと思っている．あえて蛇足を追 加するなら，上手くいかなくても煮詰まらないように複数の研究テーマを持つこと，視野を広くするために基礎寄り ・ 応用寄りの両テーマを持つこと, 宝くじょりは確率がよいので特許申請は面倒がらずに，といったところか．もちろん， 私が研究を始めたころと今とでは状況も随分変わったし, そもそも研究の進め方は人それぞれ, 分野によってもさまざ まだろう。それでも，多少とも参考になれば幸いです. 